\title{
latrogenic Chlorpromazine Abuse in a Kitten
}

\author{
Erdem Gülersoy ${ }^{*}$, Mehmet Umut Akgün, Büşra Burcu Erol and \\ Mehmet Maden
}

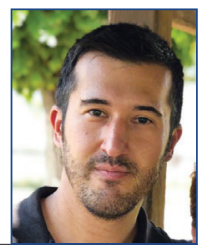

\begin{abstract}
Chlorpromazine is a sedative effective phenothiazine derivative used to prevent nausea and vomiting, especially in cases of motion sickness in cats. It has serious side effects at high doses, including weakness, tremors, loss of anal sphincter tone and reflexes, hypotension, heart rhythm abnormalities, coma, agitation and seizures. In this case report, chlorpromazine toxicity was defined in a 4-month-old, $1.2 \mathrm{~kg}$ male Van kitten brought to Selcuk University Veterinary Faculty Emergency Clinic with complaints of stagnation, tremors, vomiting and excessive sleepiness. Hypothermia (35.2 $\left.{ }^{\circ} \mathrm{C}\right)$, hyperpnea (88 breaths/min), hypersalivation, constipation, excessive agitation, tremors and incoordination were determined in the clinical examination of the kitten. It was learned from the anamnesis that $100 \mathrm{mg}$ chlorpromazine was given orally before the trip against motion sickness. Electrocardiographic examination determined sinus tachycardia (220 beats/min), increase in $\mathrm{P}$ wave amplitude, elevation in ST complex
\end{abstract}

and hypotension $(\mathrm{S} / \mathrm{MAP} / \mathrm{D}=148 / 124 / 112)$. The major laboratory findings were metabolic acidosis ( $\mathrm{pH} 7.278$ ), hypoglycaemia $(61 \mathrm{mg} /$ $\mathrm{dL})$, leukocytosis $\left(22.43 \mathrm{~m} / \mathrm{mm}^{3}\right)$, increase in blood ured nitrogen $(17.7 \mathrm{mg} / \mathrm{dL})$, creatinine $(0.6 \mathrm{mg} / \mathrm{dL})$ and ALP $(121 \mathrm{U} / \mathrm{L})$ concentrations and hypertriglyceridemia (122 $\mathrm{mg} / \mathrm{dL})$. Based on the anamnesis, clinical, laboratory and ECG findings, the kitten was diagnosed with overdose chlorpromazine toxicity and hospitalized, and put under surveillance for continuous cardiac monitoring. Lactated ringer solution, norepinephrine tartrate, furosemide, activated charcoal and oxygen therapy were given. The treatment was successful. In conclusion, it was evaluated that continuous cardiac monitoring and controlling hypotension were important in the management of chlorpromazine toxicity, and fluid therapy, norepinephrine, diuretic and activated charcoal administrations achieve success in treatment.

Key words: sedative; toxicity; motion sickness; cat

\section{Introduction}

Chlorpromazine hydrochloride $(\mathrm{CPH})$ is an antipsychotic neuroleptic drug mainly used in the treatment of neurological disorders. $\mathrm{CPH}$ is effective on all layers of the central nervous system, especially at the subcortical level. It has strong antiadrenergic and weak peripheral anticholinergic activity. Ganglionic blockade is relatively

Erdem GÜLERSOY*, DVM, PhD, Assistant Professor, (Corresponding author, e-mail: egulersoy@selcuk. edu.tr), Mehmet Umut AKGÜN, DVM, Büşra Burcu EROL, DVM, Mehmet MADEN, DVM, PhD, Full Professor, Selcuk University, Faculty of Veterinary Medicine, Konya, Turkey 
weak. In addition, it has mild antihistaminic, antiseratonergic, sedative, hypotensive and antiemetic activities. The antipsychotic activity of $\mathrm{CPH}$ is associated with blockage of D2 dopamine receptors in the brain (Haddad and Winchester, 1990). At high doses, CPH can completely block D2 dopamine receptors and seriously impair the neurotransmission of nigrostrial, mesolimbic, mesocortical dopaminergic pathways, hypothalamic dopamine neurons, and peripheral dopaminergic areas (Poisindex, 2006). CPH is commonly metabolised in the liver and excreted through the kidneys (Li et al., 2008). The metabolism pathway is cytochrome P450 isoenzyme CYP2D6, CYP1A2 and CYP3A4. Approximately 10-12 metabolites have been identified in this pathway. N-oxide occurs by hydroxylation at positions 3 and 7 of the phenothiazine nucleus and demethylation of the N-dimethylaminpropyl side chain. $20 \%$ of CPH and its metabolites are excreted in the urine in unconjugated form. The remaining $80 \%$ are conjugated metabolites (Leucht et al., 2003). CPH causes hypotension with alpha adrenergic blockade (Trepanier, 2010). It has also been reported to cause an increase in serum glucose and cholesterol levels, and blockages in the sodium, calcium and potassium channels ( $\mathrm{Li}$ et al., 2008; FDA Label, 2017).

Chlorpromazine is used for sedative purposes, especially in cats against motion sickness and to eliminate nausea and vomiting (Gollakner, 2019). It can be used in case of motion sickness and nausea $(0.1-2.2 \mathrm{mg} / \mathrm{kg}$, IV, TID), in cases of non-severe vomiting (0.1-2.2 $\mathrm{mg} / \mathrm{kg}$, PO, BID) and for sedation purposes (0.5 $\mathrm{mg} / \mathrm{kg}$ IM or IV) (Dollery and Boobis, 1992). It is fast-acting, with clinical symptoms developing within 1-2 hours of use. At high doses, it can cause tremors, drowsiness, loss of reflexes and anal sphincter tone in cats. Coma, agitation, seizures, abnormal heart rhythm and severe hypotension are the main side effects (Gollakner, 2019).

\section{Description of the Case}

This case report describes the toxicity of chlorpromazine in a 4-month old male Turkish Van cat weighing $1.2 \mathrm{~kg}$. The cat was given a $100 \mathrm{mg}$

Table 1. Blood gases, hemogram and serum biochemistry findings

\begin{tabular}{|c|c|c|}
\hline \multicolumn{2}{|l|}{ Blood gases } & Reference \\
\hline $\mathrm{pH}$ & 7.27 & $7.35-7.45$ \\
\hline Potassium mmol/L & 3.8 & $3.4-5.6$ \\
\hline Sodium mmol/L & 157 & $150-165$ \\
\hline Chlorine $\mathrm{mmol} / \mathrm{L}$ & 127 & $104-128$ \\
\hline Glucose mg/dL & 61 & $64-170$ \\
\hline Lactate $\mathrm{mmol} / \mathrm{L}$ & 3.1 & $0-2$ \\
\hline Base excess $\mathrm{mmol} / \mathrm{L}$ & -15.3 & $-4-4$ \\
\hline $\mathrm{HCO}_{3}(\mathrm{P}, \mathrm{st}) \mathrm{mmol} / \mathrm{L}$ & 11.5 & $19-24$ \\
\hline Haematology & & Reference \\
\hline WBC $\mathrm{m} / \mathrm{mm}^{3}$ & 22.43 & $5.0-19.0$ \\
\hline Lymphocyte $\mathrm{m} / \mathrm{mm}^{3}$ & 6.68 & $0.2-5.7$ \\
\hline Monocyte $\mathrm{m} / \mathrm{mm}^{3}$ & 0.96 & $0.1-1.1$ \\
\hline Granulocyte $\mathrm{m} / \mathrm{mm}^{3}$ & 14.79 & $2.0-15.2$ \\
\hline $\mathrm{RBC} \mathrm{M} / \mathrm{mm}^{3}$ & 6.89 & $4.0-9.0$ \\
\hline $\mathrm{MCV} F \mathrm{~F}$ & 51.4 & $35.5-55.0$ \\
\hline $\mathrm{MCH} \mathrm{Pg}$ & 14.2 & $16.0-24.0$ \\
\hline $\mathrm{MCHC} \mathrm{g} / \mathrm{dL}$ & 27.6 & $28.0-40.0$ \\
\hline Serum Biochemistry & & Reference \\
\hline BUN mg/dL & 17.7 & $4.7-14.3$ \\
\hline Creatinine $\mathrm{mg} / \mathrm{dL}$ & 0.6 & $0.8-1.80$ \\
\hline ALP U/L & 121 & $10-80.00$ \\
\hline ALT U/L & 51 & $10-80.00$ \\
\hline Albumin $\mathrm{g} / \mathrm{dL}$ & 2.9 & $2.1-3.90$ \\
\hline Triglycerides mg/dL & 122 & $10-114.0$ \\
\hline Cholesterol mg/dL & 139 & $90-205.0$ \\
\hline Total Protein g/dL & 5.4 & $5.4-7.80$ \\
\hline
\end{tabular}

$\mathrm{HCO}_{3}$ : Bicarbonate, WBC: Leukocyte, RBC: Erythrocyte, MCV: Mean corpuscular volume, MCH: Mean corpuscular haemoglobin, MCHC: Mean corpuscular haemoglobin concentration, BUN: Blood urea nitrogen, ALP: Alkaline phosphatase, ALT: Alanine transaminase. 
dose of chlorpromazine (Largactil ${ }^{\circledR}$, Eczacibaş1) orally by the owner against motion sickness, and within 2-3 hours of administration of the drug, it was brought to the Selcuk University, Faculty of Veterinary Medicine, Emergency Clinic with complaints of stagnation, tremor, vomiting, and excessive sleepiness.

In the anamnesis of the kitten, it was learned that an overdose of chlorpromazine was given orally against motion sickness. On physical examination, hypothermia $\left(35.2^{\circ} \mathrm{C}\right)$, hyperpnea ( 88 breaths/ $\mathrm{min})$, hypersalivation, fall in nictitating membrane (third eyelid), constipation, excessive agitation, tremor and incoordination were determined. Laboratory analysis of blood gases (Radiometer ABL 90 automatic analyzer, Model 5700, 74351, USA), haemogram (MS4 CFE 279, France), serum biochemistry (BT 3000 plus, Biotecnical Inc, SPA, Rome, Italy), urine dipstick analysis ( URIT-50Vet, Guangxi, China), ECG (Edan IM8 Vet, standard bipolar lead system (I, II and III; $50 \mathrm{~mm} /$ second; $101 \mathrm{~mm}=1 \mathrm{mV}$ ) and echocardiography (SIUI Apogee 3500, right parasternal long and short axis

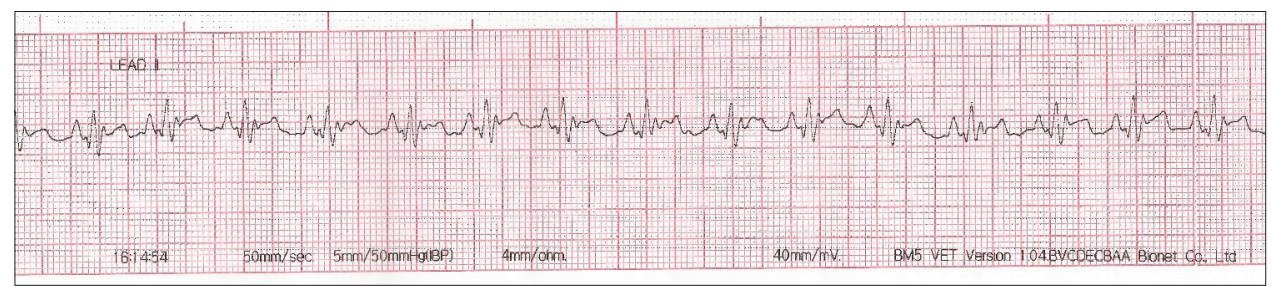

Figure 1. ECG findings

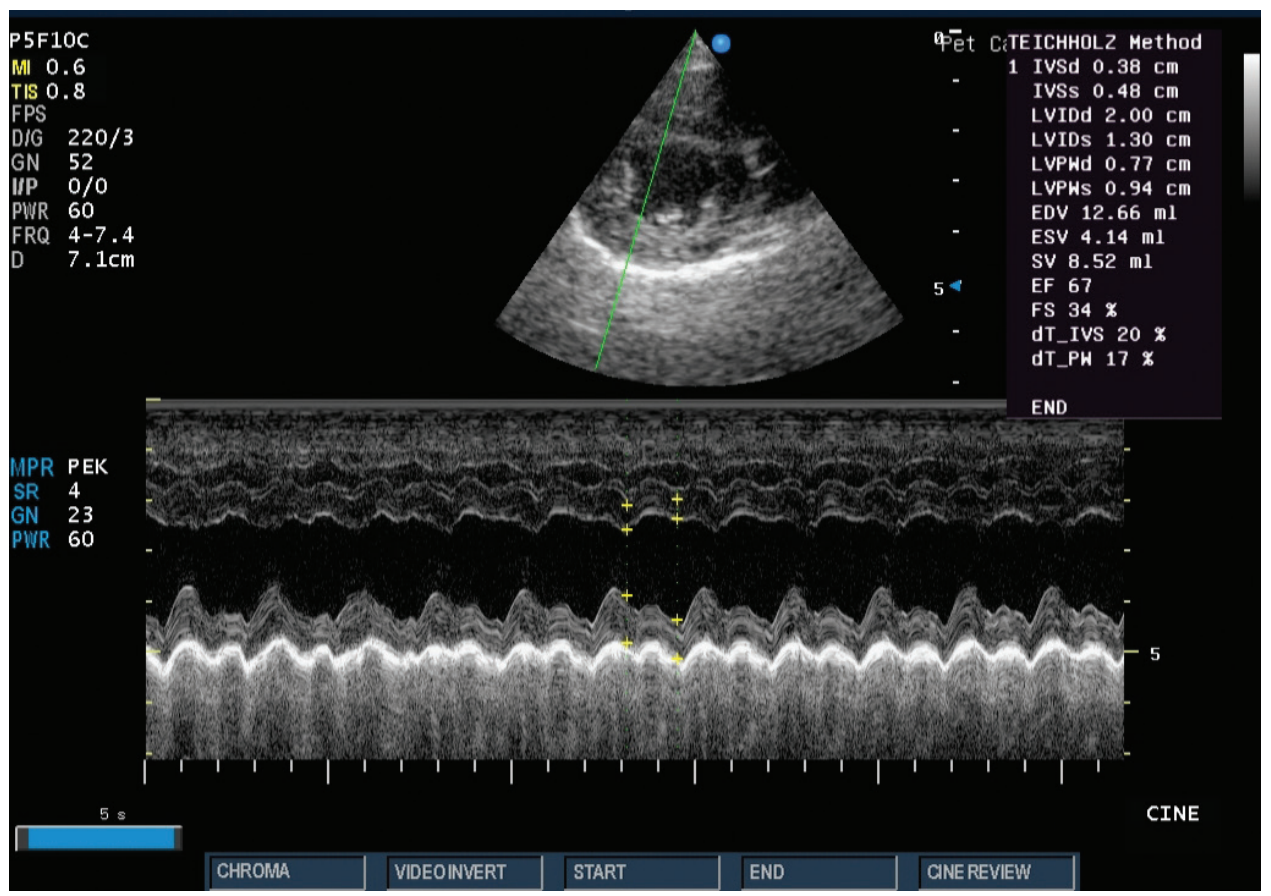

Figure 2. Echocardiographic findings 
2D and M-mode) were performed. The blood gas analysis showed metabolic acidosis, severe base deficit, and hypoglycaemia; the haemogram analysis detected leukocytosis; serum biochemistry showed increases in BUN, creatinine, ALP and triglyceride concentrations (Table 1), while the urine dipstick analysis findings were normal.

The electrocardiograph showed sinus tachycardia (220 bpm), increase in $\mathrm{P}$ wave amplitude and elevation in ST complex (Figure 1), along with normal echocardiograph findings (Figure 2).

In line with the anamnesis, clinical, laboratory and ECG findings, the kitten was diagnosed with overdose chlorpromazine toxicity. The kitten was hospitalized, and put under surveillance for continuous cardiac monitoring. To control hypothermia, the kitten was kept in a temperature and oxygen ratio adjustable incubator. Oxygen supplementation (50 $\mathrm{mL} / \mathrm{kg} / \mathrm{min}$ ) and fluid therapy (Lactated Ringer's solution $60 \mathrm{~mL} / \mathrm{kg}$, IV, Polyplex, Polifarma ${ }^{\circledR}$ ) were administrated. Norepinephrine tartrate $(10 \mu \mathrm{g} / \mathrm{kg}$, IV, Cardenor, Defarma $\left.^{\circledR}\right)$ for control of hypotension, furosemide (1 mg/kg, IM, Diuril, Vetaş $\left.{ }^{\circledR}\right)$ for diuresis and activated charcoal (1 g/ kg, PO, Dimetrol, Anadolu $\left.{ }^{\circledR}\right)$ to prevent toxin absorption were given. The kitten was discharged with normal clinical and cardiovascular findings after 24 hours. According to the information received from the animal owner, two days after discharge the cat was reported to still exhibit sleepiness, though seven days after discharge, all symptoms disappeared.

\section{Discussion}

The main side effects of $\mathrm{CPH}$ are central nervous system depression, such as sleepiness and coma. Cardiovascular toxicity of $\mathrm{CPH}$ results in ECG abnormalities such as postural hypertension, AV block, ventricular tachycardia, prolonged QT interval, ventricular fibrillation, or cardiac arrest (Haddad and Winchester, 1990). ECG abnormalities associated with the use of chlorpromazine at high doses and hypotension have been reported to be due to alpha adrenergic blockade (Trepanier, 2010). Based on normal echocardiographic examination findings, the cardiac abnormalities detected in this presented case (Figure 1) were evaluated to be based on alpha adrenergic blockade. As a result of the effect of $\mathrm{CPH}$ on the autonomic nervous system, vasodilation, hypotension and tachycardia developed. Saliva and gastric secretions were reduced. In early or mild toxicities, patients may experience restlessness, photosensitivity, urinary retention, agitation, akathisia, dystonia and confusion. Tremors due to dopamine antagonism, muscle tics, spasms, rigidity, convulsions, muscle hypotonia, torticollis, opistotonus and ocular lesions can be seen (Trepanier, 2010). Although hyperthermia can be seen, hypothermia is more common (Nunes et al., 1996). Constipation, dyspnea, cyanosis, respiratory collapse, distress and rarely excessive antidiuretic hormone $(\mathrm{ADH})$ release, water retention, liver damage, cholestatic icterus are other clinical symptoms (Baselt and Cravey, 1995). In this case, clinical symptoms were determined as hypothermia, hyperpnea, hypersalivation, fall in nictitating membrane, constipation, excessive agitation, tremor and incoordination.

Overdose reports include haematological changes such as agranulocytosis, eosinophilia, leukopenia, haemolytic anaemia, aplastic anaemia, thrombocytopenic purpura, pancytopenia and hyper/hypoglycaemia and glucosuria (PIM, 2005). In addition, high alkaline phosphatase (ALP) levels (Cares et al., 1957), hypertriglyceridemia and hyponatremia have been reported in serum biochemistry for therapeutic use of $\mathrm{CPH}$ and its toxicities (FDA Label, 2017). In the presented case, metabolic acidosis, severe base 
deficit, leukocytosis, hypoglycaemia, increase in serum BUN, creatinine, ALP and triglyceride concentrations were detected. The absence of haematological abnormalities, such as anaemia and pancytopenia, is interpreted to be due to the acute period of toxicity (Table 1 ).

Appropriate symptomatic and supportive therapy is recommended for $\mathrm{CPH}$ toxicity. In the presence of hypotension, intravenous administration of noradrenaline or phenylephrine, balanced fluid therapy, control of hypothermia, oral administration of activated charcoal to prevent absorption of the drug, and use of diazepam or lorazepam for the treatment of seizures are important (Currance et al., 2005; AHFS Drug Info, 2010; FDA Label, 2017). Due to the opposite effect and the risk of aspiration pneumonia, the use of emetic drugs should be avoided (FDA Label, 2017). In combination with $\mathrm{CPH}$, acetaminophen, antacids, antidiarrheal mixtures, bromocriptine, buspiron, cabergoline, calcium channel blockers, central nervous system depressant agents, desmopressin, diazoxide, dipiron, dopamine, doxorubicin, epinephrine, laxatives, loop diuretics, opiates, drugs that cause prolonging in QT interval, tricyclic antidepressants or quinidine should be used with caution (AHFS Drug Info, 2010; Gollakner, 2019). Although it is still considered effective in dogs to stimulate decontamination and emesis with activated charcoal, its use in cats has decreased. For this reason, although the proper use of activated charcoal is beneficial, clinicians should evaluate the benefits and risks prior to its use (Means and Wismer, 2018). In the management of this case, since it has no specific antidote, treatment success was achieved with a symptomatic and supportive treatment protocol consisting of a combination of heat and oxygen support, fluid therapy, norepinephrine tartrate, furosemide and activated charcoal.
Chlorpromazine toxicity, which is the subject of this case report, is presented for the first time based on the available information. The case was successfully treated with symptomatic and supportive treatment approaches, based on clinical and laboratory findings. In conclusion, it has been evaluated that in the management of chlorpromazine toxicity, continuous cardiac monitoring, control of heart frequency and rhythm, control of blood pressure and body temperature are very important, while the administration of IV fluids, norepinephrine, diuretic and activated charcoal contributed to the successful outcome.

\section{References}

1. American Society of Health System Pharmacists (2010): AHFS Drug Information Essentials. In: $1^{\text {s }}$ ed, Maryland, Bethesda (2510).

2. BASELT, R. C. and R. H. CRAVEY (1995): Disposition of Toxic Drugs and Chemicals in Man. In: $4^{\text {th }}$ ed., California, Chemical Toxicology Institute (158-162).

3. CARES, R., E. ASRICAN, M. FENICHEL, P. SACK and J. SEVERINO (1957): Therapeutic and toxic effects of Chlorpromazine among 3,014 Hospitalized Cases. Am. J. Psychiatry 114, 318-327.

4. CURRANCE, P. L., B. CLEMENTS and A. C., BRONSTEIN (2005): Emergency Care For Hazardous Materials Exposure. In: $3^{\text {rd }}$ ed., Missouri, Elsevier Mosby (160-161).

5. DOLLERY, C. T. and A. R. BOOBIS (1992): Therapeutic Drugs. In: $1^{\text {st }}$ ed., Edinburgh Churchill Livingstone (810-814).

6. FDA Label. Sanofi-Aventis New Zealand Limited Largactil (Chlorpromazine). https:// genesight.com/wp-content/uploads/2017/05/ Chlorpromazine-Thorazine-FDA-Label.pdf. Accessed on: 11 May 2020.

7. GOLLAKNER, R. (2019): Chlorpromazine. https:// vcahospitals.com/know-your-pet/chlorpromazine. Accessed on: 26 May 2020.

8. HADDAD, L. M. and J. F. WINCHESTER (1990): Clinical Management of Poisoning and Drug Overdose. In: $2^{\text {nd }}$ ed, Philadelphia, W.B. Saunders Company (780-793).

9. International Programme on Chemical Safety (2005): In: Poisons Information Monograph: Chlorpromazine (PIM). http://www.inchem.org/ pages/pims.html. Accessed on: 11 May 2020.

10. LEUCHT, S., K. WAHLBECK, J. HAMANN and W. KISSLING (2003): New generation antipsychotics versus low-potency conventional antipsychotics: a 
systematic review and meta-analysis. Lancet 361, 1581-1589.

11. LI, T., Q. ZHOU, N. ZHANG and Y. LOU (2008): Toxic effects of chlorpromazine on Carassius auratus and its oxidative stress. J. Environ. Sci. Heal. B. 43, 638-643.

12. MEANS, C. and T. WISMER (2018): An Overview of Trends in Animal Poisoning Cases in United States: 2011 to 2017. Vet. Clin. N. Am. Small. 48, 899-907.
13. NUNES, N., A. A. CAMACHO, S. N. KRONKA and J. L. O. COSTA (1996): Electrocardiographic study of the anesthetic combination of ketamine and chlorpromazine HCL in felines. Braz. J. Vet. Res. An. Sci. 33, 313-316.

14. Poisindex (2006): Thomson Micromedex. In: Truven Health Analytics (266-273).

15. TREPANIER, L. (2010): Acute Vomiting in Cats Rational Treatment Selection. J. Felin. Med. Surg. $12,225-230$

\section{Jatrogena zloporaba klorpromazina u mačića}

Dr. sc. Erdem GÜLERSOY, dr. med. vet., docent, Mehmet Umut AKGÜN, dr. med. vet., Büşra Burcu EROL, dr. med. vet., dr. sc. Mehmet MADEN, dr. med. vet., redoviti profesor, Univerzitet Selcuk, Veterinarski fakultet, Konya, Turska

Klorpromazin je derivat fenotiazina sa sedativnim učinkom, a rabi se za sprječavanje mučnine i povraćanja, posebice u slučajevima bolesti kretanja u mačaka. Pri velikim dozama ima ozbiljne nuspojave poput slabosti, drhtanja, gubitka tonusa analnog sfinktera i refleksa, hipotenzije, abnormalnosti srčanog ritma, kome, uznemirenosti i napadaja. U ovoj analizi slučaja, u četveromjesečnog mačića turske pasmine van težine 1,2 kg koji je doveden na hitnu pomoć Veterinarskog fakulteta Selcuk Sveučilišta s primjećenim simptomima stagnacije, drhtanja, povraćanja i prekomjerne pospanosti otkriveno je trovanje klorpromazinom. Kliničkim pregledom mačke utvrđena je hipotermija $\left(35,2{ }^{\circ} \mathrm{C}\right)$, hiperpneja (88 udisaja/min), hipersalivacija, konstipacija, prekomjerna uznemirenost, drhtanje i nekoordinacija. Iz anamneze je otkriveno da je mačić prije puta oralno primio 100 mg klorpromazina, za sprječavanje bolesti kretanja. $\mathrm{Na}$ elektrokardiografskom pregledu ustvrđena je sinusna tahikardija
(220 otkucaja/min), povećanje amplitude $\mathrm{P}$ vala, podizanje ST segmenta i hipotenzija (S/ $\mathrm{MAP} / \mathrm{D}=148 / 124 / 112)$. Glavni laboratorijski nalazi bili su metabolička acidoza ( $\mathrm{pH} 7,278)$, hipoglikemija (61 mg/dL), leukocitoza (22,43 $\left.\mathrm{m} / \mathrm{mm}^{3}\right)$, povećanje koncentracije ureje u krvi $(17,7 \mathrm{mg} / \mathrm{dL})$, kreatinina $(0,6 \mathrm{mg} /$ dL) i ALP (121 U/L) i hipertrigliceridemija (122 mg/dL). Prema anamnezi, kliničkim, laboratorijskim i EKG nalazima, mačiću je dijagnosticirano trovanje prekomjernom dozom klorpromazina te je hospitaliziran, uz kontinuirano praćenje rada srca. Mačić je primao Ringerov laktat, norepinefrin tartrat, furosemid, aktivni ugljen i terapiju kisikom. Liječenje je bilo uspješno. Zaključno, procijenjeno je da su kontinuirano praćenje rada srca i kontrola hipotenzije bile važne $\mathrm{u}$ liječenju trovanja klorpromazinom te da tekuća terapija, norepinefrin, diuretik i aktivni ugljen postižu uspjeh u liječenju.

Ključne riječi: sedativ, trovanje, bolest kretanja, mačka 